\title{
Detection of the Activities of Multiple Protein Kinases in Lipopolysaccharide-Stimulated Macrophages by Renaturation
}

\author{
Hiroto Shinomiya ${ }^{1)}$, Osamu Murakami ${ }^{1,2)}$, Masayasu Nakano ${ }^{3)}$ and Sayaka Utsumi ${ }^{1)}$ \\ ${ }^{1)}$ Department of Immunology and Host Defenses, Ehime University School of Medicine \\ ${ }^{2)}$ Department of Surgery, Shiga Medical College \\ ${ }^{3}$ Department of Microbiology, Jichi Medical School
}

Past studies of individual kinases have demonstrated that protein phosphorylation plays a crucial role in the intracellular signaling pathway of bacterial lipopolysaccharide (LPS). However, no one has determined how many kinases may be activated collectively by LPS stimulation. We examined the spectrum of protein kinases activated in macrophages in response to LPS. Activity was assessed by a renaturation method that exploited the ability of proteins denatured with sodium dodecyl sulfate and then blotted onto a membrane to regain enzymatic activity after guanidine treatment. Seven electrophoretically-distinct protein kinases with apparent molecular masses of $78,74,62,59,58,52$, and $48-\mathrm{kDa}$ were detected in lysates from unstimulated murine peritoneal macrophages. An additional three kinases, with apparent molecular masses of 82, 55, and 46-kDa, were detected when the macrophages were stimulated with LPS. The activation of these protein kinases may be dictated by complex signals that are delivered by receptor complexes, including Toll-like receptor 4 . These results should provide a clue to clarifying the pleiotropic action of LPS on macrophages.

Key words lipopolysaccharide, macrophage, phosphorylation, protein kinase

\section{INTRODUCTION}

Bacterial lipopolysaccharide (LPS) has an unusually wide range of biological effects on the host $^{1-3}$, and the principal target of LPS is the macrophage. LPS is one of the most potent bacterial components in stimulating macrophages to produce a variety of mediators, such as interleukin-1, tumor necrosis factor, and arachidonic acid metabolites. These mediators lead to inflammatory vascular changes, fever, and, in severe cases, septic shock ${ }^{4,5}$. Understanding of the molecular mechanisms whereby LPS stimulates macrophages should be helpful in the development of clinical measures to cope with septic shock.

Over the past ten years it has been demonstrated by several groups, including ours, that protein phosphorylation plays a crucial role in the intracellular signaling pathway of $\mathrm{LPS}^{6-12}$. Many different kinases, including some yet to be identified, have

Received: April 26, 2001

Revised: July 16, 2001

Accepted : July 19, 2001 been shown to contribute to LPS-induced phosphorylation in cells. However, each study investigated a particular kinase exclusively, and no examination has been made of how many kinases are activated by LPS stimulation. This prompted us to explore the whole spectrum of kinases that are activated in macrophages upon exposure to LPS.

\section{MATERIALS AND METHODS}

\section{Preparation of peritoneal macrophages}

Macrophages were obtained from specific pathogen-free 7-8 wk-old $\mathrm{C} 3 \mathrm{H} / \mathrm{HeN}$ mice (Clea Japan Inc., Osaka, Japan), and cultured in RPMI 1640 medium supplemented with $0.2 \% \mathrm{NaHCO}_{3}, 10$ $\mathrm{mM}$ HEPES, $2 \mathrm{mM}$ L-glutamine, $100 \mathrm{U} / \mathrm{ml}$ of penicillin, $100 \mu \mathrm{g} / \mathrm{ml}$ of streptomycin, and $1 \%$ fetal calf serum (FCS) (low endotoxin; Hyclone Laboratories, Logan, UT) (FCS-RPMI), as previously described $^{6-8}$. The use of uninfected mice was essential because spontaneously activated macrophages show an enhanced level of protein phosphorylation similar to that induced by LPS. The LPS content in the 


\section{H. Shinomiya et al.}

media was less than $0.1 \mathrm{ng} / \mathrm{ml}$ as tested by the Toxicolor Test (Seikagaku Kogyo Co., Tokyo, Japan).

\section{Kinase renaturation assay}

To examine the effect of LPS stimulation on the activities of renaturable protein kinases in macrophages, the modified kinase renaturation assay method of Ferrell and Martin ${ }^{13}$ was used. Macrophages were cultured in FCS-RPMI $\left(10^{6} \mathrm{ml} /\right.$ well $)$ for periods of 0 to $2 \mathrm{~h}$ in the presence of $1 \mu \mathrm{g} / \mathrm{ml}$ of chromatographically-purified protein-free LPS from Salmonella typhimurium (Sigma Chemical Co., St. Louis, MO). After incubation, the medium was drained thoroughly and $100 \mu$ l of boiled sodium dodecyl sulfate (SDS) lysis buffer (2.3\% SDS, 62.5 $\mathrm{mM}$ Tris, $5 \mathrm{mM}$ EDTA, $10 \%$ glycerol, plus $5 \%$ 2-mercaptoethanol, $\mathrm{pH}$ 6.8) was added to the cells. The lysates were scraped into microcentrifuge tubes, submerged in boiling water for $3 \mathrm{~min}$, vortexed briskly, and centrifuged for $5 \mathrm{~min}$ to pellet the insoluble debris.

Samples containing equivalent amounts of protein or prestained molecular weight standards were first separated on a 13\% SDS-polyacrylamide gel electrophoresis (SDS-PAGE) according to the method of $\mathrm{Laemmli}^{14}$. Then the samples were electrophoretically transferred to a polyvinylidene difluoride (PVDF) membrane (Millipore Corp., Bedford, MA) using a transfer apparatus in $192 \mathrm{mM}$ glycine-25 mM Tris transfer buffer without SDS or methanol. The PVDF membrane was incubated for $1 \mathrm{~h}$ at $4{ }^{\circ} \mathrm{C}$ by gentle rocking in $7 \mathrm{M}$ guanidine $\mathrm{HCl}$ (Sigma, grade I)-50 mM Tris-50 mM dithiothreitol-2 mM EDTA ( $\mathrm{pH} 8.3$ ), washed briefly with Trisbuffered saline, and allowed to renature overnight at $4^{\circ} \mathrm{C}$ in the renaturation buffer $(140 \mathrm{mM} \mathrm{NaCl}, 10$ $\mathrm{mM}$ Tris, $2 \mathrm{mM}$ EDTA, $2 \mathrm{mM}$ dithiothreitol, $0.1 \%$ Nonidet P-40, $1 \%$ bovine serum albumin, $\mathrm{pH} 7.4$ ).

The blot was blocked with $5 \%$ bovine serum albumin in $30 \mathrm{mM}$ Tris at room temperature for $1 \mathrm{~h}$, and overlaid with kinase reaction buffer $(30 \mathrm{mM}$ Tris, $10 \mathrm{mM} \mathrm{MgCl}_{2}, 2 \mathrm{mM} \mathrm{MnCl}_{2}, 50 \mu \mathrm{Ci} / \mathrm{ml}$ of $\left[\gamma^{-32} \mathrm{P}\right]$ ATP, pH $7.4 ; 1 \mathrm{ml} / 10 \mathrm{~cm}^{2}$ blot area) for 30 min at room temperature. The reaction was stopped by removing the kinase buffer and rinsing the blot with $30 \mathrm{mM}$ Tris, pH 7.5. To reduce background radioactivity, the blot was washed with $1 \mathrm{M} \mathrm{KOH}$ for $10 \mathrm{~min}$ at $37^{\circ} \mathrm{C}$. The membrane was rinsed several times with water followed by $10 \%$ acetic acid and air dried. For detection, the membrane was subjected to autoradiography for an appropriate time at $-80^{\circ} \mathrm{C}$. The bands were quantified by densitometric analysis (NIH Image). The PVDF blot was stained with Coomassie blue after autoradiography to ascertain the transfer of proteins.

\section{RESULTS AND DISCUSSION}

After macrophages were cultured in presence or absence of LPS, the macrophage samples were lysed and subjected to denaturing gel electrophoresis. Proteins were transferred to a blotting membrane, treated with guanidine, allowed to renature, and assayed for kinase activity by incubation with $\left[\gamma^{-32}\right.$ P] ATP. Radiolabels were detected in at least seven electrophoretically-distinct bands of 78, 74, 62, 59, 58,52 , and $48-\mathrm{kDa}$ in unstimulated macrophages (Fig. 1A, lanes 1, 3, and 5). We designated these putative kinases as PK78, PK74, and so on, according to their apparent molecular masses. Each band appeared to correspond to a distinct protein kinase. In addition to these kinases, the activities of three other kinases, PK82, PK55, and PK46, were detected in macrophages as early as $15 \mathrm{~min}$ after LPS stimulation and declined after $60 \mathrm{~min}$ of stimulation (Fig. $1 \mathrm{~A}$, lanes 2, 4, and 6; and Fig. 1B).

This study revealed for the first time that macrophages possess many protein kinase activities, even when they are not stimulated with LPS. At least seven electrophoretically-distinct kinases were routinely detected in samples from unstimulated macrophages by the renaturation method, and three additional kinases were detected after LPS stimulation. Because not all protein kinases can regain activity after renaturation, we think more than three kinases may be activated by LPS stimulation. $\square$ The renaturation method has an advantage over the usual kinase assay methods in being able to detect many distinct kinases simultaneously ${ }^{13}$. Although it is not yet known whether any of these kinases are related to known kinases, it is intriguing that the apparent molecular masses of the three kinases, PK82, PK55 and PK46, are similar to those of IkappaB kinase 1 (IKKI；85-kDa), protein kinase C (PKC ; 77-kDa), interleukin-1 receptor-associated kinase 1 (IRAK-1; 76-kDa), protein kinase A (PKA; 55-kDa), two mitogen-activated protein kinases, Erk-1 (44-kDa) and c-Jun N-terminal kinase (JNK; 44-kDa), or casein kinase II (CKII; 45-kDa). Each of the kinases has been shown or suggested to be rapidly activated by LPS in respective $\square$ reports $^{6-12,15-18}$; so they may correspond to the three kinases. 

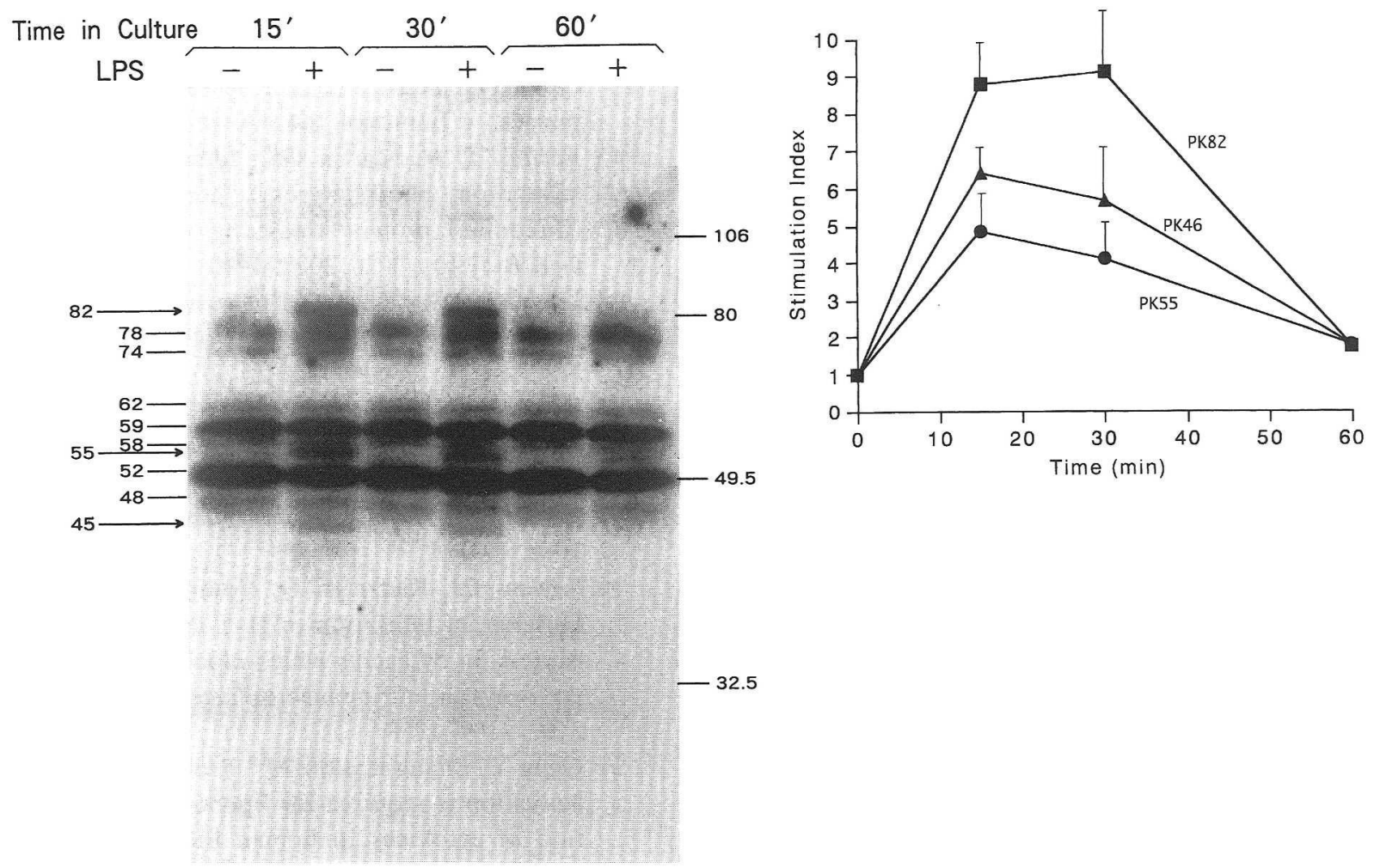

Fig. 1. Renaturation of protein kinases in LPS-stimulated macrophages. Lysates from macrophages cultured in presence or absence of LPS $(1 \mu \mathrm{g} / \mathrm{ml})$ for 15,30 , and $60 \mathrm{~min}$ were prepared and subjected to SDS-PAGE. Proteins were transferred to a PVDF membrane, treated with guanidine, allowed to renature, and overlaid with $\left[\gamma^{-32} \mathrm{P}\right]$ ATP for $30 \mathrm{~min}$. The PVDF blot was washed, air dried, and subjected to autoradiography. (A) Resultant autoradiogram. Molecular mass markers are indicated in kilodaltons on the right side of the autoradiogram. (B) The bands were quantified by densitometric analysis. Data are expressed as a stimulation index compared with the unstimulated value, which was set at 1.0. Values are expressed as the mean $+\mathrm{SD}$ of three separate experiments.

Regardless, this study revealed activation of multiple protein kinases, an interesting and previously undocumented finding. Protein phosphorylation induced by LPS has been studied for at least ten years. Many studies, performed under various experimental conditions, have shown that, as a whole, LPS activates many kinases. But none established that multiple kinases are activated by LPS within a single type of cell since each of the studies focused on a particular kinase. Therefore, we examined the spectrum of the LPS-inducible kinases in macrophages. We believe that the findings of the present study are important to understanding the pleiotropic action of LPS on macrophages ${ }^{2}$, and could explain why a variety of protein kinase inhibitors differentially suppress the various biological activities of LPS $^{15-17}$.

Mechanisms by which LPS can stimulate multiple kinases in macrophages have not been clarified. In this respect, Toll-like receptor 4 (TLR4) has recently been identified as a functional receptor for
LPS $^{18,19}$. Several different kinases may exist downstream of the TLR4-initiated pathway, or TLR4initiated signals may cross-activate kinases in other pathways. Alternatively, as shown by PY Perera, et al. ${ }^{20}$, LPS-inducing multimeric receptor complexes, which can elicit complex patterns of signaling, composed of CD14, TLR 4 and CD11b/CD18 may lead to the activation of multiple kinases.

\section{ACKNOWLEDGMENTS}

This work was partially supported by Grant-inAid \#01570243 from the Japanese Ministry of Education, Science, Sports and Culture.

\section{REFERENCES}

1 Morrison DC, Ryan JL: Bacterial endotoxins and host immune responses. Adv Immunol 28: 293347, 1979

2 Raetz CRH, Ulevitch RJ, Wright SD, Sibley CH, 
Ding A, Nathan CF: Gram-negative endotoxin: an extraordinary lipid with profound effects on eukaryotic signal transduction. FASEB (Fed Am Soc Exp Biol) J 5 : 2652-2683, 1991

3 van Deventer SJH, Buller HR, ten Cate JW, Sturk A, Pauw W: Endotoxaemia : an early predictor of septicaemia in febrile patients. Lancet 1:605-610, 1988

4 Adams DO, Hamilton TA: The cell biology of macrophage activation. Ann Rev Immunol 2: 283312, 1984

5 Nathan CF : Secretory products of macrophages. J Clin Invest 79: 319-325, 1987

6 Shinomiya H, Hirata H, Nakano M : Purification and characterization of the $65-\mathrm{kDa}$ protein phosphorylated in murine macrophages by stimulation with bacterial lipopolysaccharide. J Immunol 146 : 3617-3625, 1991

7 Shinomiya $H$, Hirata $H$, Saito $S$, Yagisawa $H$, Nakano M: Identification of the 65-kDa phosphoprotein in murine macrophages as a novel protein. Biochem Biophys Res Commun 202: 1631-1637, 1994

8 Shinomiya H, Hagi A, Fukuzumi M, Mizobuchi M, Hirata H, Utsumi S: Complete primary structure and phosphorylation site of the 65-kDa macrophage protein phosphorylated by stimulation with bacterial lipopolysaccharide. J Immunol 154: 34713480, 1995

9 Thelen M, Rosen A, Nairn AC, Aderem A: Regulation by phosphorylation of reversible association of a myristoylated protein kinase C substrate with the plasma membrane. Nature 351: 320-322, 1991

10 Weinstein SL, Gold MR, DeFranco AL: Bacterial lipopolysaccharide stimulates protein tyrosin phosphorylation in macrophages. Proc Natl Acad Sci USA 88: 4148-4155, 1991

11 Dong Z, Qi X, Fidle IJ : Tyrosin phosphorylation of mitogen-activated protein kinases is necessary for activation of murine macrophages by natural and synthetic bacterial products. J Exp Med 177 : 10711080, 1993

12 Caivano $\mathrm{M}$, Cohen $\mathrm{P}$ : Role of mitogen-activated protein kinase cascades in mediating lipopolysaccharide-stimulated induction of cyclooxygenase- 2 and IL-1 beta in RAW264 macrophages. J Immunol 164: 3018-25, 2000

13 Ferrell. E Jr, Martin GS: Identification of a 42kilodalton phosphotyrosyl protein as a serine (threonine) protein kinase by renaturation. Mol Cell Biol 10: 3020-3027, 1990

14 Laemmli UK: Cleavage of structure proteins during the assembly of the head of bacteriophage T4. Nature 227:680-683, 1970

15 Dong Z, Qi X, Fidler IJ : Tyrosin phosphorylation of mitogen-activated protein kinases is necessary for activation of murine macrophages by natural and synthetic bacterial products. J Exp Med 177 : 1071 1080, 1993

16 Kovacs EJ, Radzioch D, Young HA, Varesio L: Differential inhibition of IL-1 and TNF- $\alpha$ mRNA expression by agents which block second messenger pathways in murine macrophages. J Immunol 141 : 3101-3109, 1988

17 Geng Y, Zhang B, Lotz M : Protein tyrosine kinase activation is required for lipopolysaccharide induction of cytokines in human blood monocytes. J Immunol 1993; 151: 6692-6701.

18 Hoshin K, Takeuchi O, Kawai T, Sanjo H, Ogawa $\mathrm{T}$, Takeda Y, Takeda K, Akira S: Toll-like receptor 4 (TLR4)-deficient mice are hyporesponsive to lipopolysaccharide: evidence for TLR4 as the Lps gene product. $J$ Immunol. 162: 3749-375, 1999

19 Poltorak $\square$ A, He $\square$ X., Smirnova $\square \mathrm{I}$, Liu $\square \mathrm{M} \square \mathrm{Y}$, Huffel $\square$ CV, Du $\square$ X, Birdwell $\square$ D, Alejos $\square$ E, Silva $\square$ M, Galanos $\square$ C, Freudenberg $\square$ M, Ricciardi-Castagnoli $\mathrm{P} \square$ Layton $\mathrm{B} \square$ Beutler B. : Defective LPS signaling in $\mathrm{C} 3 \mathrm{H} / \mathrm{HeJ}$ and $\mathrm{C} 57 \mathrm{BL} /$ 10ScCr mice : mutations in Tlr4 gene. Science 282 : 2085-2088 $\square \square 1998$

20 Perera PY, Mayadas TN, Takeuchi O, Akira S, Zaks-Zilberman M, Goyert SM, Vogel SN : CD11b/CD18 acts in concert with CD14 and Tolllike receptor (TLR) 4 to elicit full lipopolysaccharide and taxol-inducible gene expression. J Immunol. 166: 574-81, 2001 